\author{
С. М. Мельник \\ кандидат юридичних наук, начальник \\ Військово-юридичного інституту \\ Національного юридичного університету ілені Ярослава Мудрого
}

\title{
АДМІНІСТРУВАННЯ РЕФОРМУВАННЯ СЕКТОРУ БЕЗПЕКИ І ОБОРОНИ УКРАЇНИ У КОНТЕКСТI РОЗВИТКУ СПІВРОБІТНИЦТВА 3 НАТО
}

Упродовж останніх років в Україні спостерігається активізація реформування сектору безпеки i оборони держави, а також поглиблення комплексної співпраці з Організацією Північноатлантичного договору (НАТО). Це зумовлюється підвищенням рівня військово-політичної напруги у східноєвропейському регіоні, а також численними загрозами для національної безпеки, обороноздатності і територіальної цілісності України. Своєю чергою від якості і динаміки реформування сектору безпеки і оборони залежить не лише безпека держави в цілому, а й результативність подальшого співробітництво з НАТО. Враховуючи те, що для реформування силового блоку має бути напрацьована відповідна наукова основа, актуальним завданням юридичної науки є всебічне дослідження адміністрування реформи сектору безпеки і оборони з урахуванням активізації співпраці України і НАТО.

Оцінка змісту наукових праць вітчизняних дослідників, які фахово займаються розробкою питань безпеки і оборони (Б. Головко, К. Гунбін, А. Дробаха, С. Зубов, О. Кунбін, С. Ліпатова, С. Крисанова, М. Орлов, С. Пасіка), свідчить про недостатню увагу науковців до комплексного наукового дослідження реформування силового компонента держави в аспекті поглиблення відносин з партнерами по НАТО. Відповідно, метою статті $\epsilon$ розкриття основних напрямів адміністрування реформи сектору безпеки і оборони держави у контексті поглиблення відносин з Північноатлантичним альянсом. Завданням наукової статті є висвітлення основних напрямів адміністративно-управлінського забезпечення реформування сектору безпеки і оборони держави.

Сектор безпеки i оборони сучасної держави представлений значною кількістю інституцій і служб. У відповідності до ст. 1 Закону України «Про національну безпеку України» від 21.06.2018 р. № 2469-VIII сектор безпеки і оборони є системою органів державної влади, Збройних сил України, інших утворених відповідно до законів України військових формувань, правоохоронних і розвідувальних органів, державних органів спеціального призначення з правоохоронними функціями, сил цивільного захисту, оборонно-промислового комплексу України, діяльність за функціональним призначенням спрямована на захист національних інтересів України від загроз [1]. Центральним елементом сектору безпеки і оборони є Збройні сили України, які є основною інституцією, яка призначена для захисту територіальної цілісності і суверенітету держави.

Починаючи з перших днів державної незалежності Україна активно розвивала партнерські відносини з НАТО. Станом на 2005 р. під час роботи Вільнюського саміту НАТО з боку керівництва Альянсу була підтверджена готовність допомогти Україні у разі реалізації наміру приєднання держави до складу альянсу [2]. Ключовою реформою на шляху України до НАТО мала стати реформа оборонної інфраструктури. Після цього основною метою зовнішніх військово-політичних відносин України і Північноатлантичного альянсу було приєднання до «Плану дій щодо набуття членства» («Membership Action Plan», або «MAP»), який передбачає програму заходів, спрямовану на вдосконалення вітчизняного законодавства у військовій сфері, а також здійснення військової реформи, підготовки фінансової, організаційної та безпекової системи держави до такого рішення.

Новий етап розвитку співробітництва України і НАТО, який заклав стратегічні основи реформування національного сектору безпеки і оборони, розпочався після проведення 8-9 липня 2016 р. Варшавського саміту НАТО. По-перше, на саміті було презентовано головний документ оборонного планування України - Стратегічний оборонний бюлетень України [3]. У документі було закріплено основні напрями реформування Збройних сил України та інших елементів сектору безпеки і оборони у контексті співпраці з НАТО (про них йтиметься пізніше). По-друге, відбулося засідання Комісії «Україна - НАТО». За результатами роботи комісії було оприлюднено Спільну заяву Комісії Україна-НАТО на рівні глав держав та урядів [4]. По-третє, Саміт затвердив Комплексний пакет допомоги (далі - КПД) з підтримки України. Для реформування Збройних сил України та всього сектору безпеки і оброни Комплексний пакет допомоги має особливе значення, Міністр оборони України назвав це «проривом» у розвитку вітчизняних Збройних сил [5]. Це пояснюється тим, що КПД приймався з метою поглиблення і посилення допомоги НАТО, що спрямована на підвищення обороноздатності України, 
а головне - проведення необхідних реформ сфери безпеки і оборони держави.

КПД містить 13 магістральних напрямів реформування сектору безпеки і оборони України. Слід зазначити, що їх реалізація є складним багатоступеневим управлінським завданням. Його успішне вирішення передбачає системну роботу як вищих органів політичного управління держави, так і суб'єктів військового управління, які мають різний статус і субординаційне підпорядкування. Відповідно, адмініструваннял процесу рефор мування сектору безпеки $і$ оборони пропонуєло вважати систелу взаєлоузгоджених управлінсько-правових заходів, яких вживають вищі орга ни політичного керівництва держави, а також суб'єкти військового управління задля організаиійного, кадрового, інфорлаиійного, технологічного, матеріально-технічного забезпечення структур но-функиіональних перетворень органів $і$ служб, які входять до сектору безпеки і оборони держави. Такі заходи реалізуються у межах пріоритетних напрямів співробітництва України і НАТО:

1) Розбудова спроможностей оборонних інституиій України (передбачає посилення демократичного контролю над Збройними силами та сектором безпеки, сприяння реформі безпекових та оборонних інституцій, покращення системи професійної військової освіти в Україні, заснування функціональної системи перепідготовки та соціальної адаптації військовослужбовців);

2) Колп'ютеризація структур управління, зв'язку, а також посилення спроможностей у галузі військового коландування (передбачає комп'ютеризацію управлінської інфраструктури Збройних сил України з метою забезпечення взаємосумісності систем управління та зв'язку України з НАТО, розвитку здатності України забезпечувати власну оборону тощо. Натепер провідні країни НАТО узгодили проекти щодо надання Україні обладнання для захищеного тактичного зв’язку ( (STC») і започаткування співробітництва в рамках Регіональної програми НАТО з безпеки повітряного простору («RASP») для координації дій цивільних та військових органів, транскордонної співпраці з НАТО у вирішенні безпекових проблем у повітряному просторі);

3) Створення узгодженої та ефективної систели логістичної підтрилки з фокусол на поліпшення спроложностей Украӥни щодо управління систелою постачання та стандартизаиї (вказаний напрям передбачає реалізацію трьох перспективних цілей: 1) підвищення національних спроможностей Збройних сил 3 кодифікації; 2) поліпшення можливостей управління системою постачання; 3) покращення можливостей управління стандартизацією);

4) Покращення технічної взаєлосулісності між Україною та НАТО (задля реалізації цьо- го напряму було створено Спільну робочу групу з оборонно-технічної співпраці, а також Цільового фонду з логістики та стандартизації. Технічна сумісність зразків озброєнь України і НАТО є однією з найбільш складних для вирішення проблем, вирішення якої потребує значного часу і ресурсів. Суб'єкти військового управління Збройних сил України порівняно з військовими підрозділами держав-членів НАТО часто виявлялись непристосованими оперативно та якісно вирішувати завдання управління. Особливо це проявлялося в умовах надзвичайних ситуацій $[6$, с. 16]. Нині триває робота з адаптації національної військової інфраструктури до стандартів НАТО і зміна технічних умов виробництва, зберігання, ремонту і застосування озброєнь. Зокрема, арсенал озброєння Збройних сил України поповнюється новими зразками зброї, техніки забезпечення проведення військових операцій та ін.);

5) Посилення рівня кібербезпеки сектору безпеки і оборони (передбачає впровадження новітніх заходів кібернетичної безпеки у функціонування органів і підрозділів сектору безпеки і оборони. Відповідні заходи будуть реалізовуватись завдяки функціонуванню Цільового фонду з кіберзахисту, який надаватиме Україні обладнання та навчальні програми для ефективної протидії кіберзагрозам. Фонд надає Україні допомогу, необхідну для розвитку їі оборонних технічних можливостей для протидії інформаційним диверсіям, створення команди реагування на інциденти в галузі кібербезпеки головних органів військового управління (Міністерство оборони, Генеральний штаб). Допомога включає надання обладнання для лабораторій з розслідування випадків хакерських атак та створення Центру реагування на кіберінциденти. Проект має також навчальний та дорадчий вимір, адаптований під національний контекст України. Слід зазначити, що нині проект функціонує. Відбулися перші тренінгові та консультативні роботи з майбутніми системними адміністраторами в установах НАТО, зараз також реалізується додатковий запит української сторони на підготовку чергової групи фахівців. Триває робота також над обгрунтуванням концептуальних підходів до визначення норм опрацювання різних видів інформації посадовою особою органу військового управління $з$ урахуванням біологічних можливостей людини [7, с. 21]);

6) Посилення енергетичної безпеки воєнної інфраструктури (передбачає підготовку спеціалістів із захисту критичної оборонної інфраструктури від загроз енергетичного дефіциту. Реалізується через обмін досвідом, організацію спільних тренувальних програм та навчальних курсів з енергетичної безпеки);

7) Впровадження ефективної систели медичної підтрилки за Євроатлантичнили 
стандартали (передбачає безпосередню медичну допомогу військовим, поліпшення швидкого доступу до послуг з медичної та психологічної реабілітації, розвиток спроможностей закладів медичної реабілітації в Україні, які зможуть надавати медичні послуги військовослужбовцям. Передбачає налагодження взаємодії з іноземними фахівцями у зазначеному напрямі, що має принципово велике значення для України. Так, вітчизняними експертами неодноразово наголошувалося, що запровадження в Україні практики використання коштів Міністерства оборони на лікування військовослужбовців у приватних лікарнях сприяло б більш ефективній реабілітації останніх [8, с. 208]. У 2018 р. функцію управління медичним забезпеченням почав виконувати спеціальний управлінський підрозділ - Головне військово-медичне управління. Головне військово-медичне управління призначене для організації медичного забезпечення Збройних сил України, управління медичною службою Збройних сил, участі у забезпеченні реалізації державної політики в галузі охорони здоров'я військовослужбовців, членів їхніх сімей, ветеранів війни та інших категорій громадян, визначених нормативними актами. Функціонує зазначений орган у відповідності до стандартів НАТО [9]).

8) Знешкодження саморобних вибухових пристроїв, боєприпасів, що не вибухнули, та їх розмінування (передбачає створення надійної спеціальної системи протидії загрозам від саморобних вибухових пристроїв та боєприпасів, що не вибухнули. Вказаний напрям реформ буде здійснюватися за підтримки партнерів НАТО зі знешкодження саморобних вибухових пристроїв та боєприпасів, що не вибухнули);

9) Активізаиія наукової та освітньої діяльності в срері оборони і національної безпеки (передбачає активізацію наукових розробок, предметом яких є протидія тероризму, розвиток військових технологій, кіберзахисту оборонної інфраструктури, забезпечення енергетичної безпеки військ, протидія застосуванню хімічної, біологічної, радіологічної та ядерної зброї. Також у межах цього пріоритету реалізується ще одне важливе завдання програми - сприяння Україні в удосконаленні системи базової військової освіти та професійної підготовки. Програма взяла на себе довгострокову функцію сприяння двосторонній підтримці країн НАТО з метою формування у Збройних силах України нового сержантського складу за стандартами Альянсу);

10) Посилення спроложностей національних сил оборони України в галузі стратегічних колунікацій (передбачає формування чіткої структурованої системи комунікації складників сектору безпеки і оборони з відповідними службами НАТО в ординарному режимі та за особливих умов сус- пільно-політичного характеру, коли на військовослужбовців вчиняється негативний інформаційно-психологічний вплив [10, с. 85]. Проєкти 3 розвитку спроможностей у сфері стратегічних комунікацій включають навчальні тренінги та семінари, навчальні інформаційні поїздки українських військових спеціалістів за кордон тощо);

11) Підвищення потенціалу України у протидіï гібриднил війнал (НАТО сприятиме у створенні платформи з вивчення досвіду ведення гібридних бойових дій в Україні. Гібридні конфлікти складаються із багаторівневих дій, спрямованих на дестабілізацію дієвої держави і поляризацію ïï суспільства i, на відміну від звичайних бойових дій, «центром тяжіння» гібридної війни є цільова група населення [11]. Інформаційні і розвідувальні можливості НАТО в частині вивчення особливостей гібридних війн дають змогу надавати цінні рекомендації українським спеціалістам у подоланні гібридного конфлікту на Сході України);

12) Рефорла Служби безпеки України (НАТО сприяє реформуванню СБУ, зосереджуючи увагу на питанні забезпечення цивільного демократичного контролю за діяльністю органів і підрозділів СБУ, надає експертну та дорадчу допомогу в рамках реформування СБУ. Починаючи з 1998 р. під егідою Комісії Україна-НАТО реалізуються ініціативи у сфері цивільно-військових відносин, демократичного контролю та залучення громадськості до управління діяльністю Збройних сил та інших складників сектору безпеки, оборонного планування, розробки стратегії та концепції національної безпеки);

13) НАТО надаватиле підтрилку Державній службі України з надзвичайних ситуаиій у розбудові спроможностей у галузі захисту иивільного населення та гуманітарної допомоги, зокрема в рамках діяльності Євроатлантичного координаційного центру (ЄКЦ) реагування на природні лиха та катастрофи (основне завдання - надавати сприяння Державній службі України з надзвичайних ситуацій у розбудові їі потенціалу та можливостей у сфері цивільного захисту та гуманітарної допомоги, реалізуючи заходи під егідою ЄКЦ. ЄКЦ виступає в ролі клірингового центру для координації як запитів, так і пропозицій щодо надання допомоги у разі природних і техногенних катастроф. Українські рятувальники за допомогою програм Альянсу удосконалюють національну систему планування на випадок надзвичайних ситуацій, розробляють нові методики реагування на катастрофи та захист критичної інфраструктури, беруть участь у навчаннях НАТО).

На додаток до наведеного вище доцільно зазначити, що одним із найскладніших завдань адміністрування реформи сектору безпеки і оборони України у контексті поглиблення співпраці з НАТО є перехід Збройних сил України на 
стандарти НАТО, які називаються універсальною абревіатурою «STANAG» (англ. - «Standardization Agreement»). Фактично Стандарти НАТО є міжнародною угодою, положення якої регулюють загальні правила, визначають спільний порядок дій, закріплюють єдину термінологію і встановлюють умови уніфікації технічних процесів, а також озброєння і військової техніки, іншої матеріальної частини збройних сил НАТО і держав, з якими НАТО налагоджує партнерські відносини. Стандарти НАТО об’єднані в складну і взаємопов' язану ієрархію нормативних документів. Їх систему експерти умовно поділяють на три групи: адміністративні, оперативні та матеріально-технічні [12].

Слід зауважити, що впровадження STANAG у практику функціонування Збройних сил України, про що ми частково вже зазначали, є найбільш складним завданням, яке вимагає комплексного перегляду всієї інфраструктури вітчизняного ВПК та функціонування системи Збройних сил України. Перехід на стандарти НАТО забезпечує планомірне нарощування рівня боєздатності частин і підрозділів Збройних сил України, сприяє підвищенню ефективності використання державних ресурсів у сфері оборони, удосконалює систему підготовки військових частин і підрозділів, що входять до складу багатонаціональних військових формувань, та зростанню авторитету України на міжнародному рівні [13]. Впровадження стандарту НАТО - це комплекс заходів, що містить прийняття рішення на застосування у Збройних силах положень (норм, вимог) стандарту НАТО, розроблення на основі стандарту НАТО відповідного акта законодавства чи нормативного документа (внесення відповідних змін та/чи доповнень до чинних документів), надання йому чинності в установленому порядку, застосування розробленого на основі стандарту НАТО документа у повсякденній діяльності Міноборони та Збройних сил. Натепер для підготовки України до вступу у НАТО у функціонування Збройних сил України слід впровадити 765 стандартів (нормативних документів) НАТО, які поступово перекладаються українською мовою 3 мови оригіналу та впроваджуються у практику військового управління України. Але процес цей нині не завершений і триває. Практика адаптації STANAG у національну систему функціонування Збройних сил складається таким чином, що стандарти, як правило, формулюються в окремих нормативних документах, яких натепер розроблено десятки. Узагальнено, що впровадження STANAG відбувається навколо п'яти стратегічних цілей: створення об'єднаної системи керівництва силами української оборони, ефективна політика планування і застосування ресурсів, посилення боєздатності частин і з'єднань за світовими стандартами, об’єднана з НАТО логістика і система медичного забезпечення.
Натепер Україна плідно працює над реформуванням сектору безпеки і оборони i, таким чином, забезпечує всебічні умови для нарощування співпраці з НАТО. Адміністрування реформування сектору безпеки і оборони нині здійснюється активними темпами і у відповідності до чітко визначених напрямів. Разом із тим спостерігається певна проблематика реформування сектору безпеки і оборони, що зумовлено чинниками фінансового, управлінсько-правового характеру. Відповідно, перспективним напрямом наукової розробки аспектів реформування сектору безпеки і оборони України є вироблення пропозицій щодо підвищення ефективності реформування силового блоку держави.

\section{Jimepamypa}

1. Про національну безпеку України : Закон України від 21.06.2018 р. № 2469-VIII. Відомості Верховної Ради Украӥни. 2018. № 31. Ст. 241.

2. Головко В. Бухарестський саміт НАТО. Матеріали Інтернет-сайту «Цей день в історї̈. URL: https://www.jnsm.com.ua/h/0404Q/ (дата звернення: 29.01.2019).

3. Про рішення Ради національної безпеки і оборони України «Про Стратегічний оборонний бюлетень України» : Указ Президента України від 06.06.2016 p. № 240/216. Офіиійне інтернет-представництво Президента України. URL: https://www.president.gov.ua/ documents/2402016-20137/ (дата звернення: 22.05.2019).

4. Спільна заява Комісії Україна-НАТО на рівні глав держав та урядів від 9 липня 2016. Варшава. Польща. Офіційний веб-сайт організацї північноатлантичного договору. URL: https://www.nato.int/cps/en/ natohq/official_texts_133173.htm?selectedLocale $=u k$ (дата звернення: 29.01.2019).

5. Витримки з інтерв'ю Міністра оборони України «5 каналу» С. Полторака. «Комплексний пакет допомоги НАТО Україні - прорив у співпраці з альянсом». Інтернет-сайт “Defence-Express”. URL: https://defenceua.com/index.php/home-page/2186-kompleksnyypaket-dopomohy-nato-ukrayini-proryv-u-spivpratsi-zalyansom (дата звернення: 29.01.2019).

6. Зубов О.Я., Крисанова С.В. Застосування інформаційно-технічних засобів для удосконалення роботи органів військового управління Збройних сил України в надзвичайних ситуаціях. Сучасні інформаційні тех нології у сфері безпеки та оборони. Науково-практичний журнал. 2008. № 1. С. 16.

7. Орлов М.М. Про необхідність законодавчого затвердження норм інформаційного навантаження на посадових осіб органів державної влади та органів військового управління. Честь i закон. 2013. № 2. С. 21.

8. Пасіка С.П. Адміністративно-правове регулювання монетизації пільг військовослужбовців: зарубіжний досвід. Південноукраїнський правничий часоnuc. 2011. № 4. С. 208.

9. У Збройних силах сформовано єдиний орган управління медичним забезпеченням - Головне військово-медичне управління. Офіиійний вебсайт Міністерства оборони України. URL: http://www.mil.gov.ua/news/2018/01/04/u-zbrojnihsilah-sformovano-edinij-organ-upravlinnya-medichnimzabezpechennyam-golovne-vijskovo-medichneupravlinnya/ (дата звернення: 31.05.2019). 
10. Дробаха А. Ліпатов I., Гунбін К., Ліпатова С. Методика обгрунтування чисельності групи протидіi негативному інформаційно-психологічному впливу на військовослужбовців Внутрішніх військ у складі управління територіального командування. Честь $i$ за кон. 2012 . № 1 (40). С. 85.

11. Стримування гібридної війни: шанс для НATO і ЄС працювати разом? Журнал «НАТО-ревю». URL: https://www.nato.int/docu/review/2014/Alsoin-2014/Deterring-hybrid-warfare/UK/index.htm (дата звернення: 29.01.2019).

12. Сергей Мукосий «O внедрении стандартов HATO». Інтернет-сайт Інформаційно-консалтингової компанії "DEFENSE EXPRESS". URL: https:/ defence-ua.com/index.php/statti/296-sergej-mukosijsegodnya-ministerstvo-oborony-yavlyaetsyalokomotivom-sredi-vsekh-organov-vlasti-po-vnedreniyustandartov-nato (дата звернення: 25.05.2019).

13. Впровадження стандартів НАТО у Збройних силах: підсумки 2016-го. Ukrainian Military Pages. URL: https://www.ukrmilitary.com/2017/08/stanag. html (дата звернення: 29.01.2019).

\section{Анотація}

Мельник С. М. Адміністрування реформування сектору безпеки і оборони України у контексті розвитку співробітництва з НАТО. - Стаття.

У статті запропоновано авторський варіант визначення категорії «адміністрування процесу реформування сектору безпеки і оборони» як системи взаємоузгоджених управлінсько-правових заходів, яких вживають вищі органи політичного керівництва держави, а також суб'єкти військового управління задля організаційного, кадрового, інформаційного, технологічного, матеріально-технічного забезпечення структурно-функціональних перетворень органів і служб, які входять до сектору безпеки і оборони держави.

Наведено перелік і розкрито сутність основних напрямів адміністрування реформи сектору безпеки i оборони України в аспекті розвитку і подальшого поглиблення відносин з НАТО. Зокрема, це: розбудова спроможностей оборонних інституцій України, комп'ютеризація структур управління, зв'язку, а також посилення спроможностей у галузі військового командування, створення узгодженої та ефективної системи логістичної підтримки з фокусом на поліпшення спроможностей України щодо управління системою постачання та стандартизації, посилення рівня кібербезпеки сектору безпеки і оборони, посилення енергетичної безпеки воєнної інфраструктури, впровадження ефективної системи медичної підтримки за Євроатлантичними стандартами, знешкодження саморобних вибухових пристроїв, боєприпасів, що не вибухнули, та їх розмінування, активізація наукової і освітньої діяльності в сфері оборони і національної безпеки, посилення спроможностей національних сил оборони України в галузі стратегічних комунікацій, підвищення потенціалу України у протидії гібридним війнам, реформа Служби безпеки України, надання підтримки з боку НАТО Державній службі України з надзвичайних ситуацій у розбудові спроможностей у галузі захисту цивільного населення.

Окремо акцентовано увагу на тому, що одним із найскладніших завдань адміністрування реформи сектору безпеки і оборони України у контексті поглиблення співпраці з НАТО є перехід Збройних сил України на стандарти НАТО, які називаються універсальною абревіатурою «STANAG» («Standardization Agreement»). Зазначено, що впровадження «STANAG» забезпечує планомірне нарощування рівня боєздатності частин і підрозділів Збройних сил України, сприяє підвищенню ефективності використання державних ресурсів у сфері оборони, удосконалює систему підготовки військових частин і підрозділів, що входять до складу багатонаціональних військових формувань, та зростанню авторитету України на міжнародному рівні.

Ключові слова: Україна, сектор безпеки і оборони, НАТО, суб'єкти військового управління, Збройні сили України, Міністерство оборони, оборонна інфраструктура, Служба безпеки України.

\section{Summary}

Melnik S. M. Administration of the reforming of the security and defense sector of Ukraine in the context of developing cooperation with NATO. - Article.

The article proposes the author's variant for determining the category of «administration of the reforming process of the security and defense sector « as a system of mutually agreed administrative and legal measures used by the highest bodies of the political leadership of the state, as well as the subjects of military administration for organizational, personnel, informational, technological, material and technical support of structural and functional transformations of agencies and services that are a part of the security and defense sector of the state.

The list and the essence of the main directions of administration of the reforming of the security and defense sector of Ukraine in the aspect of development and further deepening of relations with NATO are outlined. In particular, it is: capacity development of Ukraine's defense institutions, computerization of administrative structures, communications, and strengthening of capabilities in the field of military command, the establishment of a coordinated and effective system of logistic support with a focus on improving Ukraine's capabilities in managing supply and standardization system, strengthening of the level of cybersecurity of the security and defense sector, strengthening of the energy security of the military infrastructure, the introduction of an effective system of medical support according to Euro-Atlantic standards, improvised explosive devices clearance, unexploded ordnance and mine clearance, activation of scientific and educational activities in the field of defense and national security, strengthening of the capabilities of the national defense forces of Ukraine in the sphere of strategic communications, enhancing Ukraine's potential in countering hybrid wars, reforming the Security Service of Ukraine, providing NATO support to the State Emergency Service of Ukraine in capacity development in the field of civil protection.

Special attention is paid to the fact that one of the most difficult tasks of administration of the reforming of the security and defense sector' of Ukraine in the context of deepening cooperation with NATO is the transition of the Armed Forces of Ukraine to NATO standards, universally abbreviated as «STANAG» («Standardization Agreement»). It is noted that the implementation of «STANAG» provides for a systematic increase in the level of combat capability of parts and units of the Armed Forces of Ukraine, promotes the increase in the efficiency of the use of state resources in the sphere of defense, improves the system of training military units and units that are a part of multinational military formations, and the increase of Ukraine's authority on the international level.

Key words: Ukraine, security and defense sector, NATO, subjects of military administration, Armed Forces of Ukraine, Ministry of Defense, defense infrastructure, Security Service of Ukraine. 